\title{
PROSES DAN HASIL BELAJAR PADA PRAKERIND BIDANG KEAHLIAN KENDARAAN RINGAN: STUDI KASUS PADA INDUSTRI PASANGAN SMKN 3 YOGYAKARTA
}

\author{
Yuneldi Miswardi \\ Disdik Pelalawan-Riau \\ myuneldi@yahoo.co.id \\ Pardjono \\ Program Pascasarjana Universitas Negeri Yogyakarta \\ jpardjono@yahoo.com
}

\begin{abstract}
Abstrak
Penelitian ini bertujuan untuk mengungkapkan proses belajar siswa SMKN 3 Yogyakarta kompetensi keahlian teknik kendaraan ringan di tempat kerja dalam pelaksanaan praktek kerja industri (prakerind). Penelitian ini menggunakan pendekatan kualitatif studi kasus. Subjek penelitian adalah empat manager/pihak DUDI yang mengelola pelaksanaan prakerind dan tujuh siswa yang terlibat dalam kegiatan prakerind pada empat DUDI tersebut. Pengumpulan data dilakukan dengan observasi dan wawancara. Teknik analisis data yang digunakan ialah metode Miles dan Huberman, melalui tahapan pengumpulan data, reduksi data, penyajian data, dan penarikan kesimpulan. Hasil penelitian adalah sebagai berikut. 1) Pengaturan belajar siswa di tempat kerja dengan membatasi jumlah siswa dalam pekerjaan dan menjadikan siswa sebagai helper mekanik. 2) Proses pembelajaran siswa di tempat kerja: (a) belajar melalui pekerjaan dengan mengikuti mekanik; (b) peran mekanik: memberikan kesempatan kepada siswa untuk melakukan pekerjaan secara langsung dengan bimbingan dan pengawasan, memberikan penilaian terhadap kinerja siswa; (c) cara siswa mendapatkan kompetensi di tempat kerja: (1) berkomunikasi dan bersosialisasi, (2) rajin dan ulet, (3) memiliki inisiatif dan aktif; (d) pengetahuan, keterampilan dan sikap yang diperoleh siswa di tempat kerja: (1) pengetahuan tentang dunia kerja bengkel otomotif dan pengalaman kerja pada pekerjaan yang sesungguhnya, (2) kategori kompetensi siswa yang diperoleh dalam prakerind untuk kategori bengkel besar dan kecil adalah kategori specialist, sedangkan untuk kategori bengkel menengah masih dalam kategori orang yang belum berpengalaman, (3) sikap siswa sesuai dengan budaya kerja di DUDI yaitu kerja keras dan peduli mutu.
\end{abstract}

Kata kunci: Pembelajaran di tempat kerja

\section{PROCESS AND LEARNING OUTCOMES AT INDUSTRIAL ATTACHMENT PROGRAM FOR LIGHT VEHICLES STUDY PROGRAM: A CASE STUDY AT PARTNERS INDUSTRIES OF SMKN 3 YOGYAKARTA}

\begin{abstract}
The objectives of this research were to describe the learning process of the students of SMKN 3 Yogyakarta of skill competence of light vehicle in the implementation of industrial practice (prakerind). This research used a case study qualitative approach. The subjects were four managers who managed the implementation of Industrial Attachment and seven students who were involved in prakerind activities at those four industries. The data collection was conducted through observations and interviews. The data analysis techniques used were Miles and Huberman methods conducted in four steps: data collection, data reduction, data presentation, and conclusion. The results of this research are as follows. 1) The arrangement of students' learning at workplace is done by limiting the number of students in working and making the students as the mechanic helpers. 2) The learning process at workplace: (a) learning by working which follows the mechanic; (b) the mechanic role: provides the opportunities to the students to work directly with guidance and supervision, gives the assessments to students' performances; (c) the students' way for getting the competencies at workplace: (1) by communicating and socializing, (2) by being diligent and tenacious, (3) by having the initiative and active; (d) knowledge, skill, and attitude obtained by the students in the workplace: (1) the students have the knowledge of the work field of automotive and the work experience at the real work, (2) the category of the students' competence obtained in prakerind for the basic category and the small category is in the specialist category, while for the middle category, it is still in the novice category, (3) the students' attitude based on the work culture in DUDI is hardwork and quality care.
\end{abstract}

Keywords : workplace learning 


\section{PENDAHULUAN}

Pendidikan kejuruan adalah salah satu bentuk pendidikan nasional di Indonesia yang didesain untuk membantu menyiapkan peserta didik untuk memasuki dunia kerja. Pendidkan kejuruan mengembangkan sikap profesional dan kemampuan berkompetisi dalam suatu bidang keahlian tertentu untuk mempersiapkan dirinya masuk ke dunia kerja. Peraturan Pemerintah Nomor 29 Tahun 1990 tentang pendidikan menengah, bab I pasal 1 ayat 3 menyatakan bahwa "Pendidikan menengah kejuruan adalah pendidikan pada jenjang pendidikan menengah yang mengutamakan pengembangan kemampuan siswa untuk melaksanakan jenis pekerjaan tertentu". Kemudian dalam bab II pasal 3 ayat (2) dinyatakan bahwa: "Pendidikan Menengah Kejuruan mengutamakan penyiapan siswa untuk memasuki lapangan kerja serta mengembangkan sikap profesional".

Permasalahan yang dihadapi oleh kalangan dunia pendidikan, khususnya Sekolah Menengah Kejuruan (SMK) adalah masih rendahnya daya serap lulusan SMK ke dunia kerja. Idealnya, secara nasional lulusan SMK yang bisa langsung memasuki dunia kerja sekitar $80-85 \%$ (Samsudi). Daya serap kelulusan masih rendah. http://www.kapanlagi. com, 31 Maret 2008). Selanjutnya Direktur Pembinaan SMK, Joko Sutrisno (Kompas. com, 26 Januari 2010) memberi keterangan yang senada bahwa pada tahun 2010 daya serap lulusan SMK ke pasar kerja sebesar 50 persen, dan sekitar 10 persen $(80.000$ 90.000) lulusan SMK melanjutkan ke jenjang pendidikan tinggi. Data penyerapan lulusan SMK tersebut masih menyisakan sekitar 40\% lulusan SMK yang belum diketahui nasibnya. Namun Joko Sutrisno juga menyatakan harapannya bahwa "Kalau tahun ini daya serap lulusan ke pasar kerja baru 50 persen, maka tiap tahun diharapkan ada kenaikan 5 persen sehingga pada 2014 lulusan SMK bisa terserap 70 persen ke dunia kerja".

Persoalan lain masih rendahnya serapan tenaga kerja lulusan SMK oleh industri disebabkan minimnya peralatan praktik yang dimiliki oleh SMK. Menurut Kepala Sekolah SMK Sunan Gunung Jati Karawang Mizaq Setiawan (Republika.co.id, 23 Maret 2012) "masih rendahnya daya serap lulusan SMK terhadap dunia industri otomotif, salah satu- nya peralatan praktik yang minim". Secara terpisah, Kepala Dinas Pendidikan Kabupaten Karawang Agus Supriatman (Republika.co.id, 23 Maret 2012) mengatakan jumlah SMK yang ada di wilayahnya mencapai 69 sekolah tetapi lulusan SMK yang diserap di perusahaan otomotif hanya 10 persen dari rata-rata kelulusan.

Berbagai upaya telah dilakukan oleh SMK untuk meningkatkan mutu lulusan dan daya serap lulusan ke dunia kerja. Upaya tersebut harus mampu mendekatkan SMK dengan dunia kerja. Sekolah memberikan dasardasar kejuruan, sedangkan dunia kerja memberikan pengalaman kerja professional yang sarat dengan nilai-nilai yang pada umumnya tidak didapat ketika di bangku sekolah.

Berdasarkan data dari Bursa Kerja Khusus SMKN 3 Yogyakarta, daya serap lulusan oleh dunia usaha/industri (selanjutnya disingkat DUDI) khususnya pada kompetensi keahlian teknik kendaraan ringan mencapai $80 \%$ selain yang melanjutkan ke Perguruan Tinggi. Capaian ini karena didukung oleh peralatan praktek yang memadai sehingga peserta didik dapat belajar teori dan praktikum.Untuk keperluan ini SMKN 3 Yogyakarta bermitra dengan BLPT Yogyakarta sebagai tempat praktikum siswa kompetensi keahlian teknik kendaraan ringan. Namun dengan semakin kompetitifnya lulusan dimasa yang akan datang, SMKN 3 Yogyakarta perlu memaksimalkan setiap tahapan proses pendidikan dan latihan yang akan dilalui siswa dalam menyelesaikan studi mereka. Salah satunya adalah kegiatan belajar siswa di DUDI melalui program prakerind.

Praktek kerja industri (Prakerind) merupakan salah satu bentuk penyelenggaraan pendidikan dan pelatihan kejuruan yang dilaksanakan di SMK. Prakerind merupakan proses belajar melalui bekerja langsung di tempat kerja yang sesungguhnya. Pengalaman yang diperoleh pada saat melakukan prakerind secara tidak langsung akan mempercepat tercapainya kondisi transisi peserta didik dari sekolah ke dunia industri. Oleh karena itu keterlibatan DUDI sangat diperlukan untuk meningkatkan relevansi lulusan untuk dapat menjembatani kesenjangan antara kompetensi yang dihasilkan sekolah dengan tuntutan DUDI. Dengan demikian upaya peningkatan kualitas lulusan SMK tidak hanya menjadi tanggung jawab SMK sendiri, melainkan juga 
menjadi tanggung jawab DUDI dan masyarakat.

Menurut Charles Prosser yang di kutip oleh Wardiman (1998), ada 16 prinsip pendidikan kejuruan dan diantaranya yang terkait dengan peran industri ada tiga prinsip. Pendidikan kejuruan akan efektif jika (a) tugastugas latihan dilakukan dengan cara, alat, dan mesin yang sama seperti yang ditetapkan di tempat kerja (b) melatih seseorang dalam kebiasaan berpikir, dan bekerja seperti yang diperlukan dalam pekerjaan itu sendiri dan (c) pendidikan kejuruan akan efisien jika lingkungan dimana siswa dilatih, merupakan replika lingkungan dimana nanti ia akan bekerja.

Secara umum DUDI belum menyadari pentingnya mendesain kegiatan belajar siswa dalam prakerind. Sehingga kehadiran siswa dalam prakerind masih menjadi beban bagi DUDI dan kekhawatiran DUDI akan resiko kegagalan hasil pekerjaan yang berarti rugi uang dan rusaknya reputasi masih tinggi. Jika DUDI mendesain kegiatan belajar siswa selama mereka melaksanakan prakerind tentu kekhawatiran tersebut tidak ada, akan tetapi dapat memberikan kepuasan tersendiri bagi DUDI yang menjadi institusi pasangan karena memperoleh pengakuan ikut serta menentukan hari depan bangsa.

Persoalan berbagi peran antara sekolah dengan DUDI dalam penyiapan lulusan SMK yang siap pakai sudah seharusnya dilakukan secara intensif oleh sekolah dengan DUDI. Berbagi peran tersebut harus diawali dengan komunikasi yang intensif selama persiapan, proses dan penyelesaian siswa belajar di tempat kerja. Berdasarkan observasi peneliti selama kegiatan pra survey ke beberapa DUDI yang menjadi institusi pasangan SMKN 3 Yogyakarta kompetensi keahlian teknik kendaraan ringan dalam prakerind, komunikasi yang terjalin antara sekolah dengan DUDI hanya sebatas formalitas penempatan siswa prakerind saja. Sehingga tidak terjalin kerja sama yang mengarah kepada optimalisasi peranan masing-masing pihak dalam mengidentifikasi kompetensi yang harus dikuasai siswa selama mereka belajar di tempat kerja. Model kerja sama yang belum menyentuh pada pembagian tugas yang terstruktur tentang apa yang di pelajari siswa di sekolah dan tata urutan pelatihan yang terstruktur di DUDI tersebut mengakibatkan siswa dituntut untuk berusaha sendiri dalam mencari apa yang harus dipelajari dan dikuasainya selama mereka belajar di tempat kerja.

Kombinasi antara belajar dan bekerja merupakan basis pembelajaran kejuruan. Peserta didik merupakan subyek yang melakukan pembelajaran di tempat kerja. Pembelajaran mereka di tempat kerja sangat berbeda dengan pembelajaran di sekolah terutama budaya dan sikap kerja yang harus mereka miliki karena di tempat kerja adalah real job. Hasil pekerjaan di DUDI diukur dengan "diterima atau ditolak" (berhasil atau gagal) sedangkan hasil pekerjaan di sekolah dipahami sebagai sebuah proses belajar bukan hasil. Perbedaan kondisi inilah yang harus mendapatkan perhatian yang lebih baik oleh pihak-pihak yang berkepentingan dengan SMK dan dunia kerja. Prakerind memungkinkan peserta didik mencapai tingkat keahlian yang jauh lebih baik dibandingkan dengan yang tidak melaksanakan prakerind. Pertanyaan umum yang muncul adalah apakah peserta didik belajar sesuatu dari dunia kerja lewat prakerind? Kalau ya, belajar apakah mereka? Apakah mereka belajar terkait dengan hard skills atau soft skills? Hard skills atau soft skills apakah yang mereka peroleh dari prakerind. Pertanyaan yang hanya sebagian dari permasalahan terkait prakerind inilah yang mendorong suatu penelitian harus dilakukan.

\section{Pembelajaran dan pelatihan di tempat kerja}

Tujuan utama pendidikan adalah tidak untuk memungkinkan siswa melakukannya dengan baik di sekolah, tetapi untuk membantu mereka melakukannya dengan baik dalam menjalani kehidupan mereka di luar sekolah. Hal itu dinyatakan oleh Ray McNulty, ICLE Iowa High School Summit, December 10, 2007 dalam Morley, 2010: 21 sebagai berikut: "The primary aim of education is not to enable students to do well in school, but to help them do well in the lives they lead outside of the school. Selanjutnya Gewertz (2007) dalam Morley (2010: 21) menyatakan bisnis dan industri memberikan pesan yang sangat jelas bahwa siswa membutuhkan keterampilan untuk "bekerja dengan nyaman dengan orang-orang dari budaya lain, memecahkan masalah secara kreatif, menulis dan berkomunikasi dengan baik, berpikir dengan cara 
yang multidisiplin, dan mengevaluasi informasi kritis serta mereka harus tepat waktu, dapat diandalkan, dan rajin".

Pembelajaran di tempat kerja menyediakan kesempatan kepada peserta didik untuk mengembangkan dan menerapkan pengetahuan, keterampilan, dan sikap kerja serta perilaku yang mengarah ke informasi pilihan karir dan pekerjaan yang lebih baik dan produktif (Morley, 2010: 40). Belajar pada pekerjaan yang sesungguhnya mengandung arti belajar dengan pengetahuan dan keterampilan yang spesifik dalam melakukan pekerjaan. Tidak semua pembelajaran terjadi di tempat pelatihan. Pada kenyataannya, sebagian besar pembelajaran terjadi sebagai hasil dari pelatihan yang dilakukan dalam pekerjaan itu sendiri, bukan di kelas pelatihan (Jacob \& OsmanGani, 1999; Wexley \& Latham, 1991 dalam Jacobs, (2003:14). Latihan pada pekerjaan (on-the-job training) terjadi di lokasi dilakukannya pekerjaan, dan sering dianggap sebagai perpaduan belajar dan melakukan pekerjaan pada saat yang sama.

\section{Situated learning theory}

Situated learning pertama kali diusulkan oleh Lave dan Wenger (1990) sebagai model pembelajaran dalam komunitas praktek. Jenis pembelajaran ini memungkinkan individu peserta didik untuk belajar dengan sosialisasi, visualisasi, dan imitasi. Brown, et. al. (1989) dalam Billet (1994: 1) mendefinisikan "Situated learning has been defined as a learner executing tasks and solving problems in an environment which reveals the various intended uses of the knowledge. Definisi tersebut menjelaskan bahwa peserta didik melaksanakan tugas dan memecahkan masalah dalam suatu lingkungan untuk mengungkap tujuan penggunaan berbagai pengetahuan. Dalam psikologi kognitif telah diungkapkan pentingnya domain pengetahuan spesifik untuk kinerja/performance seorang ahli (Glaser, 1989 dalam Billet, 1994:1). Dengan pengakuan dari peran spesifik domain pengetahuan, telah muncul pandangan bahwa pengetahuan akan lebih tertanam ketika pengetahuan tersebut ada pada dunia penerapannya (Brown, et al, 1989; Rogoff \& Lave, 1984 dalam Billet 1994: 2)

Lave dan Wenger (1990) berpendapat bahwa belajar tidak harus dilihat hanya sebagai transmisi pengetahuan abstrak dan tanpa konteks dari satu orang ke orang lain, melainkan suatu proses sosial dimana pengetahuan itu dibangun. Mereka menyarankan bahwa pembelajaran tersebut terletak dalam konteks tertentu dan tertanam dalam lingkungan fisik dan sosial tertentu pula. Selanjutnya, teori yang mendukung situated learning berasal dari penerimaan saat ini bahwa belajar sebagai proses sosial (Goodnow 1990 dalam Billet 1994: 2). Bimbingan sosial terjadi secara langsung dan tidak langsung antara lain pelajar yang lebih berpengalaman dipandang sebagai bagian penting dan tak terelakkan dari proses pembelajaran (Cazden: 1993, Goodnow: 1990, Rogoff: 1990 \& dalam pers; Scribner: 1985 \& 1990; Vygotsky: 1978 dalam Billet 1994: 2)

Bimbingan sosial yang mengarah kepada pemberian pengetahuan terdiri dari bimbingan proksimal dan distal. Vygotsky (1978) dalam Vaughan, O'Neil \& Cameron (2011: 22) pertama kali memperkenalkan konsep dari "zona pengembangan proksimal" dalam belajar. Bimbingan proksimal mengacu pada pedoman kedekatan dengan orang lain, misalnya anak yang mengikuti orang tuanya bekerja, ahli dengan pemula atau tukang dengan magang. Bentuk bimbingan ini melibatkan pemecahan masalah dan memberikan pengetahuan secara bertahap dari orang yang lebih berpengalaman kepada peserta didik sehingga mereka menjadi semakin mampu bekerja tanpa bimbingan. Bimbingan distal adalah bimbingan yang sengaja dibentuk oleh organisasi sosial, seperti pengaruh sosial, praktek-praktek budaya yang mengatur kegiatan kerja, prioritas dan nilai-nilai, sifat dari pengaturan fisik dan pengaturan struktur kelembagaan. Misalnya lembaga pendidikan formal yang mengatur praktek-praktek budaya sesuai dengan pencapaian yang ditetapkan oleh lembaga (Billett, 1993b; Rogoff \& Lave, 1984 dalam Billet 1994: 2).

Bimbingan sosial yang terjadi di tempat kerja secara proksimal melibatkan peran ahli dalam membantu peserta didik dalam belajar. Untuk menjalankan perannya sebagai mentor peserta didik, seorang praktisi ahli harus memiliki pengetahuan tentang pekerjaan sehingga mereka dapat membimbing peserta didik dalam mengkonstruksi pengetahuan dan keterampilan yang dibutuhkan untuk keberhasilan pembelajaran. Membantu orang belajar memerlukan pengalaman dan keterampilan khu- 
sus dari seorang mentor. Menurut Vaughan, O'Neil \& Cameron (2011: 23) orang yang dipilih sebagai mentor harus memiliki berbagai keterampilan dan atribut pribadi antara lain: (1) kemampuan untuk berhubungan baik dengan peserta didik dan membangun kepercayaan dan keyakinan mereka; (2) kemampuan untuk menjadi model dari keahlian mereka sendiri dalam praktek dan menjelaskan tentang hal itu secara bermakna; (3) kepekaan terhadap kemampuan tingkat pemula; (4) keterampilan dalam mengamati praktek dan menyediakan petunjuk bermanfaat; (5) kemampuan mengajukan pertanyaan untuk meningkatkan kesadaran, mengeksplorasi keyakinan pemula, memprediksi konsekuensi dan mencari solusi permasalahan; (6) Kemampuan untuk memberikan ruang kepada pemula untuk belajar sendiri pada tingkat resiko yang tidak terlalu tinggi; (7) kemampuan untuk mendorong siswa untuk "berpikir keras" dan menjelaskan keputusan mereka; (8) pengetahuan tentang persyaratan kualifikasi dan kemampuan untuk bimbingan dan praktek

\section{Kurikulum berbasis tempat kerja}

Peranan tempat kerja dalam membentuk pengetahuan dan keterampilan peserta didik semakin penting. Peserta didik belajar keterampilan kejuruan mulai dari pembelajaran awal individu dalam bekerja sampai pada pengembangan lebih lanjut pengetahuan kejuruan mereka setelah lulus semakin disadari oleh pendidik kejuruan. Oleh karena itu, kurikulum praktek kerja di tempat kerja harus diidentifikasi, dikonseptualisasi dan dievaluasi. Tanpa adanya identifikasi, konseptualisasi dan pengakuan dari kurikulum berbasis tempat kerja, maka tempat kerja akan tetap disalah pahami sebagai tempat belajar.

Menurut Billet (2006: 3-11) menjelaskan beberapa jenis kurikulum yang berbasis tempat kerja antara lain:

\section{Kurikulum sebagai niat}

Kurikulum sengaja dibuat berdasarkan kompetensi yang harus dikuasai peserta didik melalui belajar di tempat kerja. Di sini, pendekatan kurikulum difokuskan pada bagaimana peserta didik memperoleh pengetahuan dengan melakukan peran efektif mereka dalam bekerja dan mengembangkan lebih lanjut potensi mereka melalui pengalaman kerja.
Tujuan kurikulum kejuruan adalah membantu individu mengidentifikasi dan menyadari potensi kejuruannya. Kurikulum berbasis tempat kerja yang ideal terdiri dari urutan kegiatan kerja, yaitu tentang apa saja yang akan dilakukan, yang mengarah pada partisipasi penuh siswa dalam praktek kerja bidang tertentu. Proses ini disusun berdasarkan persyaratan yang diberlaku di tempat kerja, termasuk bagaimana pengaturan dan pembagian pekerjaan, serta tujuan yang akan diwujudkan melalui keterlibatan individu dalam mempelajari praktek kerja itu. Siswa dapat memulai pekerjaannya dengan tingkat resiko yang rendah, kemudian diikuti oleh pekerjaan dengan tipe kesulitan semakin tinggi.

Ada beberapa prinsip pedagogis terkait dengan proses keterlibatan siswa dalam aktivitas kerja. Namun kegiatan ini perlu disusun untuk membantu siswa belajar tentang persyaratan praktik yang efektif, tujuan yang ingin dicapai, dan menyediakan dasar untuk memantau kemajuan dan penilaian pencapaian keterampilan siswa. Tugas-tugas yang sulit dalam belajar perlu diidentifikasi dan didukung dengan memberi tugas-tugas belajar kepada peserta didik. Strategi instruksionalnya dapat melalui permodelan, pendampingan, pembimbingan, tanya-jawab, pemecahan masalah, memberi kesempatan berlatih dan mengulang kegiatan belajar sebagai bagian dari aktivitas kerja sehari-hari. Inilah yang dimaksudkan dengan kurikulum tempat kerja yang ideal atau kurikulum tempat kerja yang seharusnya disediakan, yang dimaksudkan untuk membentuk pengalaman peserta didik.

\section{Kurikulum seperti yang berlaku di tempat kerja}

Kurikulum dibuat berdasarkan keinginan pihak-pihak tertentu yang ada di DUDI. Kurikulum pembelajaran dimaksudkan untuk mencerminkan keinginan seseorang atau pihak tertentu yang ada di DUDI terhadap pengalaman yang akan didapat oleh peserta didik. Kemudahan akses memperoleh pengalaman di tempat kerja dari peserta didik diperkirakan berasal dari dukungan tiga sumber: (1) pengusaha/pengelola; (2) rekan kerja dan; (3) pelayanan dan faktor-faktor produksi. Mereka mengatur akses ke kegiatan dan interaksi siswa dalam belajar, memberikan dukungan, dan mengatur hal-hal lain untuk kemajuan peserta didik. 
Kurikulum tempat kerja seperti apa yang dialami oleh pekerja

Kurikulum dibuat berdasarkan pengalaman individu sebelumnya. Pembelajaran siswa di tempat kerja adalah kelanjutan dari pengalaman kerja mereka sebelumnya. Dalam hal ini, kontinuitas program diklat di sekolah dan praktek kerja individu saling diperkuat melalui partisipasinya dalam pekerjaan. Harus ada dialog dan pemahaman yang sama tentang kurikulum dan pengalaman belajar antara lembaga pendidikan dengan tempat kerja. Kurikulum tempat kerja merupakan elemen kunci untuk mencapai tujuan yang diharapkan dari belajar di tempat kerja melalui partisipasi dan keterlibatan siswa dalam bekerja di tempat kerja.

\section{Level kompetensi manusia dalam bekerja}

Keahlian (expertise) didefinisikan sebagai pekerjaan atau tugas yang bisa dimengerti dan dilakukan oleh seorang ahli. Orang yang memiliki kompetensi pada tingkat tertinggi biasanya disebut ahli. Tabel 1 di bawah ini menunjukkan kategori kompetensi manusia dalam taxonomi mulai dari orang yang belum berpengalaman sampai kepada master (Jacob \& Washington, 2003 dalam Jacobs, 2003: 6).

Tabel 1. Level kompetensi manusia dalam bekerja

\begin{tabular}{cl}
\hline Kategori & \multicolumn{1}{c}{ Deskripsi } \\
\hline 1 & Pemula secara harfiah, orang \\
Pemula & baru dalam suatu situasi kerja. \\
(novices) & Sering ada beberapa perbaikan \\
& tetapi minimal untuk pekerjaan \\
& sebelumnya. Sebagai hasilnya, \\
& individu kurang pengetahuan dan \\
& keterampilan untuk memenuhi \\
& persyaratan yang dibutuhkan \\
& untuk melakukan pekerjaan \\
& tertentu \\
\hline 2 & Orang yang dapat di andalkan \\
Specialist & untuk melakukan pekerjaan yang \\
& spesifik tanpa pengawasan. \\
& Tetapi terbatas pada pekerjaan \\
& rutin. Kadang-kadang diperlukan \\
& pelatih pada tingkat ini untuk \\
& membantu mereka memiliki \\
& perilaku yang sesuai. \\
\hline
\end{tabular}

\begin{tabular}{|c|c|}
\hline Kategori & Deskripsi \\
\hline $\begin{array}{c}3 \\
\text { Spesialis } \\
\text { berpenga- } \\
\text { laman }\end{array}$ & $\begin{array}{l}\text { Orang yang dapat melakukan } \\
\text { pekerjaan yang spesifik dan } \\
\text { mampu melakukannya berkali- } \\
\text { kali. Sebagai hasil, individu dapat } \\
\text { melakukan pekerjaan dengan } \\
\text { terampil dan mudah. tingkat ini } \\
\text { akan dilalui dalam beberapa } \\
\text { waktu. }\end{array}$ \\
\hline $\begin{array}{c}4 \\
\text { Ahli }\end{array}$ & $\begin{array}{l}\text { Orang yang memiliki } \\
\text { pengetahuan dan pengalaman dan } \\
\text { sering melampaui persyaratan } \\
\text { yang dibutuhkan untuk } \\
\text { melakukan pekerjaan tertentu. } \\
\text { Dapat menggunakan } \\
\text { kemampuannya untuk merespon } \\
\text { kasus-kasus rutin dan tidak rutin } \\
\text { dengan efektif dan efisien. }\end{array}$ \\
\hline $\begin{array}{c}5 \\
\text { Master }\end{array}$ & $\begin{array}{l}\text { Orang yang dianggap sebagai ahli } \\
\text { di antara ahli-ahli atau benar- } \\
\text { benar ahli d antara semua } \\
\text { pekerja. Dia dipandang sebagai } \\
\text { penilai dan menetapkan standar } \\
\text { untuk orang lain. }\end{array}$ \\
\hline
\end{tabular}

\section{Langkah-langkah dalam pembelajaran dan pelatihan di tempat kerja}

Berdasarkan analisis pekerjaan yang komprehensif, ada tujuh langkah dari proses pelatihan yang dikembangkan dari empat langkah yang dikemukakan oleh Allen's dalam Jacobs (2003:17). Ke-tujuh langkah perlu dilakukan oleh instruktur atau trainer dalam melatihkan satu kompetensi baru dalam pekerjaan.

a. Tunjukkan bagaimana melakukan

b. Jelaskan tentang poin-poin utama dalam pekerjaan yang dilakukan

c. Ijinkan dia melihat anda melakukannya lagi

d. Ijinkan dia melakukan bagian yang sederhana dari pekerjaan tersebut

e. Bantu dia melakukan seluruh pekerjaan

f. Biarkan dia melakukan seluruh pekerjaan di bawah pengawasan

g. Biarkan dia melakukan seluruh pekerjaan tanpa pengawasan

Menurut Cunningham, Dawes dan Bennet (2004: 127-128), ada lima langkah dalam pelaksanaan pembelajaran yang dapat dilaku- 
kan peserta didik di tempat kerja antara lain sebagai berikut.

a. Lakukan pendekatan terhadap pembelajaran di tempat kerja dengan sengaja dan sadar. Gunakan kontrak pembelajaran dan rencana pengembangan diri, hal ini dapat membantu dalam menetapkan orientasi dan tujuan dalam pembelajaran dari waktu ke waktu

b. Jelaskan tujuan dan harapan kepada pengawas atau manager untuk mendapatkan persetujuan mereka agar tujuan pembelajaran dan kinerja yang ditentukan dapat dicapai dalam waktu yang telah ditetapkan.

c. Jalin hubungan dengan rekan kerja dan yang lainnya untuk menggali ide-ide dan sumber-sumber potensi keahlian yang menantang untuk diri sendiri.

d. Coba dan temukan seorang rekan kerja yang dapat berperan sebagai pelatih dan berbagi capaian serta jadwal pembelajaran dengannya.

e. Buat rencana untuk melakukan review dan refleksi dari yang telah dilakukan.

\section{Keunggulan dan keterbatasan pembelajar- an dan pelatihan di tempat kerja}

Menurut Cunningham, Dawes dan Bennet (2004: 127-128), ada beberapa keuntungan dan keterbatasan dalam pembelajaran pada pekerjaan yang real (on-the-job learning) yaitu:

\section{Keunggulan}

1. On-the-job learning dapat menyediakan waktu yang tepat bagi siswa untuk belajar bekerja.

2. situasi dunia kerja yang alami dan fleksibel dapat memberikan pembelajaran pada pekerjaan yang spesifik.

3. orang dapat belajar dengan melakukan dan berkesempatan untuk mempraktekkannya.

4. Sangat baik dalam rangka pengembangan pengetahuan dan keterampilan dasar dalam bekerja.

\section{Keterbatasan}

1. Pembelajaran di tempat kerja tidak akan berhasil tanpa dukungan langsung dari lingkungan kerja.
2. Dalam periode yang terbatas kinerja yang dicapai lebih rendah dari yang diharapkan.

\section{METODE PENELITIAN}

\section{Jenis penelitian}

Fokus penelitian ini adalah untuk mengungkap bagaimana proses belajar peserta didik berlangsung di tempat kerja dalam pelaksanaan prakerind. Pertnyaan penelitian yang harus mendapatkan jawaban pada penelitian ini adalah: (1) apa peran atau posisi di tempat kerja dari peserta prakerind, (2) bagaimana proses belajar dalam rangka prakerind; (3) bagaimana peserta prakerind memperoleh kompetensi di tempat kerja, (4) seberapa tingkatan keahlian yang bisa dicapai pasca prakerind dan apakah ada perbedaan tingkatan keahlian untuk bengkel yang berbeda, (5) sikap-sikap apakah sebagai hasil belajar peserta prakerind yang sesuai dengan yang diperlukan oleh dunia kerja.

Pertanyaan penelitian di atas memerlukan pendekatan penelitian yang mampu mengungkap realitas di balik fenomena terindera, yaitu dengan pendekatan post-positivistik. Daya sertap SMK 3 Negeri Yogyakarta memiliki daya serap lulusan oleh dunia kerja yang sudah mencapai $80 \%$. Oleh karena tradisi atau jenis studi kasus digunakan agar mampu menggali realitas yang sebenarnya.

Penelitian dilaksanakan selama 3 bulan dari November 2012 sampai dengan Januari 2013. Penelitian ini dilakukan di Nasmoco Bantul yang berlokasi di Jl. Ring Road Selatan Taman Tirto Bantul, bengkel Rally Autocare yang berlokasi di Jl. Gedongkuning No. 44B Yogyakarta, bengkel Maestro yang berlokasi di Jl. Raya Janti No. 263 Yogyakarta, Bengkel Agus yang berlokasi di Jl. Kabupaten Km. 2,4 Trihanggo Gamping Sleman dan, BLPT Yogyakarta yang berlokasi di Jl. Kyai Mojo No. 70.

Responden untuk penelitian ini adalah 1 (satu) orang Instruktur bengkel, 2 (satu) orang manager bengkel, dan 1 (satu) orang pemilik bengkel yang mengelola siswa prakerind di DUDI serta 7 (tujuh) orang perwakilan siswa yang sedang melaksanakan prakerind pada masing-masing DUDI.

Metode pengumpulan data yang digunakan dalam penelitian ini adalah metode 
wawancara mendalam dan observasi. Wawancara dilakukan untuk menggali data pengaturan belajar siswa oleh DUDI dalam pelaksanaan prakerind dalam hal ini adalah pihak DUDI yang berwenang mengelola prakerind. Data dari DUDI adalah sebagai data pendukung untuk melihat lebih jauh tentang proses belajar siswa di DUDI. Selanjutnya kepada siswa yang telah selesai melaksanakan prakerind sebagai data utama untuk melihat proses belajar siswa dalam pelaksanaan prakerind.

Melalui wawancara, diharapkan peneliti mendapatkan informasi tentang pengaturan belajar siswa oleh DUDI dan proses belajar siswa di tempat kerja selama pelaksanaan prakerind. Untuk membantu peneliti supaya masalah yang diteliti fokus, maka dibuatlah pedoman wawancara berupa garis-garis besar permasalahan yang akan ditanyakan.

\section{Teknik menjagga keabsahan data}

Data yang diperoleh perlu dijaga kredibilitas dan keabsahannya. Teknik keabsahan data yang dilakukan dalam penelitian ini adalah dengan triangulasi sumber yang merupakan bagian dari kriteria derajat kepercayaan (credibility).

Data penelitian adalah data kualitatif yang berupa hasil wawancara yang telah ditranskrip. Analisis data dilakukan secara induktif, dengan menggunakan prosedur dari Miles \& Huberman (....) yaitu menganalisis data melalui prosedur reduksi data, display data, penympulan, dan verifikasi.

Reduksi data dilakukan untuk memilih aspek-aspek informasi yang relevan dengan fokus penelitian. Hal ini dilakukan karena data bisanya terkontaminasi dengan data yang tidak diperlukan. Dalam penelitian ini, reduksi data berlangsung terus-menerus selama proses penelitian berlangsung yaitu melaksanakan pemilihan data yang diperoleh dari wawancara dan observasi ke DUDI selama siswa prakerind dan wawancara setelah siswa menyelesaikan pelaksanaan prakerind.

\section{HASIL PENELITIAN DAN PEMBAHASAN}

\section{Peran Peserta Prakerind dan posisi peserta prakerind.}

Pada waktu peserta prakerind sampai di tempat prakerind, mereka kemudian diberi pengarahan dan ditempatkan pada bagian ter- tentu dan berfungsi membantu atau penanggung jawab suatu pekerjaan. Hasil wawancara menunjukkan bahwa untuk pertama kali peserta prakerind masuk bengkel mereka diberi status sebagai helper. Arti kata helper adalah pembantu di bengkel kendaraan ringan yang mempunyai tugas utama membantu mekanik yang ada.

\section{Kepedulian DUDI Terhadap Penyiapan SDM}

Terungkap dalam penelitian ini adalah bahwa, DUDI mempunyai kepedulian terhadap kebutuhan sumber daya manusia yang akan datang untuk keperluan mereka sendiri hanya bisa dipenuhi selama DUDI memiliki kesadaran dan merasa berkepentingan.

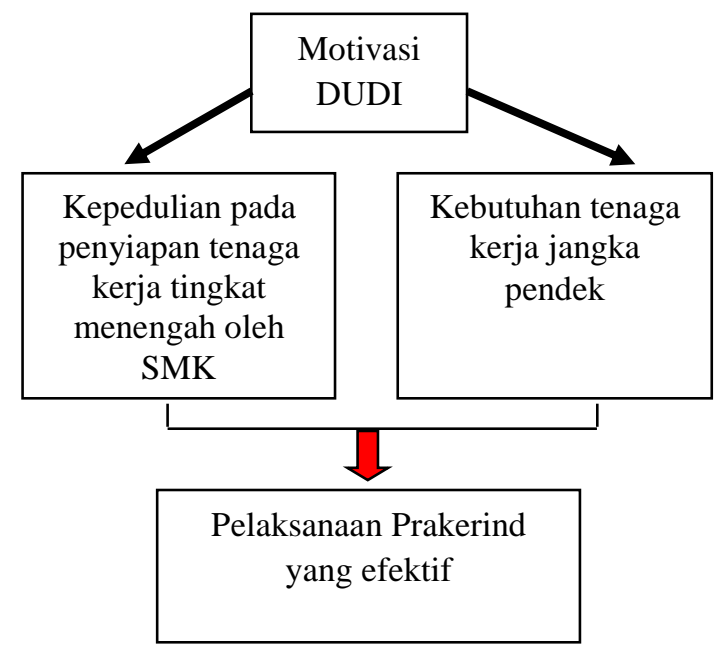

Gambar 1. Motivasi DUDI

Gambar 1 di atas menunjukkan motivasi DUDI dalam menerima siswa prakerind di tempat mereka, agar pelaksanaan prakerind berjalan efektif dan saling menguntungkan. Siswa mendapatkan akses belajar melalui pekerjaan dan DUDI juga merasa terbantu pekerjaannya dengan adanya siswa prakerind. Dukungan DUDI terhadap program prakerind tidak lepas dari motif keuntungan bagi mereka. Dengan adanya peserta prakerin dari SMK para mekanik mendapatkan bantuan helper dan bengkel tempat praktik memperoleh tenaga tambahan tanpa memberikan gaji tambahan.

\section{Peran Mentor}

Mekanik di DUDI memiliki peran sebagai pembimbing, model, instruktur keteram- 
pilan tertentu yang belum pernah diperoleh di bangku sekolah. Sebagai pembimbing mereka memberi pengarahan, petunjuk, dan memberi pengetahuan baru. Banyak keterampilan dan tacit knowledges yang tidak bisa dipelajari di bangku sekolah melalui role model dari mekanik sebagai ahli. Mekanik juga berperan sebagai pelatih keterampilan yang belum pernah dialami oleh peserta prakerind.

Peran eduksi lain dari mentor adalah memberikan penilaian hasil prakerind dari peserta prakerind karena merupakan bagian dari tugas pembimbing. Sesuai dengan teori belajar situated learning di mana bimbingan sosial dapat mengarah kepada terjadinya transfer pengetahuan secara proximal. Proximal mengacu pada pedoman kedekatan dengan orang lain, misalnya orang tua bekerja dengan anaknya, orang belum dewasa dengan guru, ahli dengan pemula melalui sistem magang. Bimbingan yang diberikan oleh mekanik merupakan bimbingan proksimal, yaitu bentuk bimbingan yang sedikit tetapi menyebabkan pemula berkembang maksimal. Bentuk bimbingan ini sering dalam bentuk permasalahan yang harus dipecahkan oleh pemula, kemudian secara bertahap akan terjadi konstruksi kemampuan mengakuisisi pengetahuan dari pekerja yang lebih berpengalaman. Peserta prakerind sebagai pekerja pemula pada akhirnya akan menjadi semakin mampu bekerja tanpa bimbingan (Billett: 1993b, Rogoff \& Lave: 1984 dalam Billet: 1994).

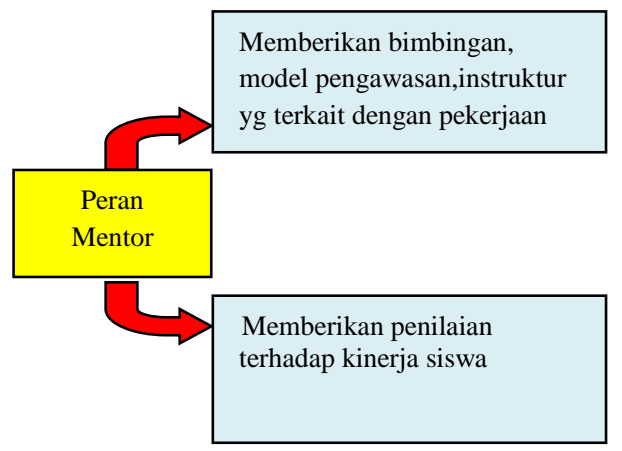

Gambar 2. Peran instruktur/pembimbing

Secara garis besar terdapat dua peran utama mekanik sebagai pembimbing siswa yang merupakan temuan dari penelitian ini antara lain:

1) Memberikan kesempatan kepada siswa untuk melakukan pekerjaan secara langsung dengan bimbingan dan pengawasan.
2) Memberikan penilaian terhadap kinerja siswa (apakah siswa akan diberikan kepercayaan untuk bekerja mandiri atau tidak)

Tingkat kompetensi (skills) yang diperoleh siswa peserta prakerind sebagai wujud dari tata urutan pelatihan yang dilakukan mekanik dalam membimbing siswa akan di bahas pada poin berikutnya. Jika diurutkan lebih rinci, tata urutan pelatihan di atas relevan dengan tujuh langkah proses pelatihan yang dikembangkan dari empat langkah yang dikemukakan oleh Allen's dalam Jacobs (2003:17). Ke tujuh langkah perlu dilakukan oleh instruktur atau trainer dalam melatihkan satu kompetensi baru dalam suatu pekerjaan adalah sebagai berikut.

1) Tunjukkan bagaimana melakukan

2) Jelaskan tentang poin-poin utama dalam pekerjaan yang dilakukan

3) Ijinkan dia melihat anda melakukannya lagi

4) Ijinkan dia melakukan bagian yang sederhana dari pekerjaan tersebut

5) Bantu dia melakukan seluruh pekerjaan

6) Biarkan dia melakukan seluruh pekerjaan di bawah pengawasan

7) Ijinkan dia melakukan seluruh pekerjaan tanpa pengawasan

\section{Kompetensi yang diperoleh siswa selama prakerind}

Kompetensi yang diperoleh siswa dalam prakerind adalah semua pekerjaan yang dilakukan oleh siswa selama prakerind di tempat kerja. Pada umumnya pekerjaan yang dilakukan siswa di tempat kerja sesuai dengan kompetensi di sekolah yang tertuang dalam kurikulum kompetensi keahlian teknik kendaraan ringan yaitu engine, power train, chasis \& suspension dan electrical. Artinya terdapat korelasi antara kompetensi yang di ajarkan di sekolah dengan jenis pekerjaan di tempat kerja.

\section{Cara siswa mendapatkan kompetensi di tempat kerja (Soft skill)}

Di depan dijelaskan bahwa peserta prakerind belajar dengan membantu mekanik dalam bekerja. Dan tidak adanya tata urutan pelatihan yang terstruktur oleh mekanik terhadap kompetensi yang harus dikuasai oleh 
siswa, secara tidak langsung siswa harus mencari sendiri kompetensi yang harus dipelajarinya melalui pekerjaan dengan melakukan cara-cara tertentu untuk mendapatkan kepercayaan mekanik. Kepercayaan yang mungkin diberikan oleh mekanik untuk mengerjakan sebagian atau keseluruhan pekerjaan kepada siswa merupakan suatu prestasi yang baik dari pelaksanaan prakerind oleh siswa.

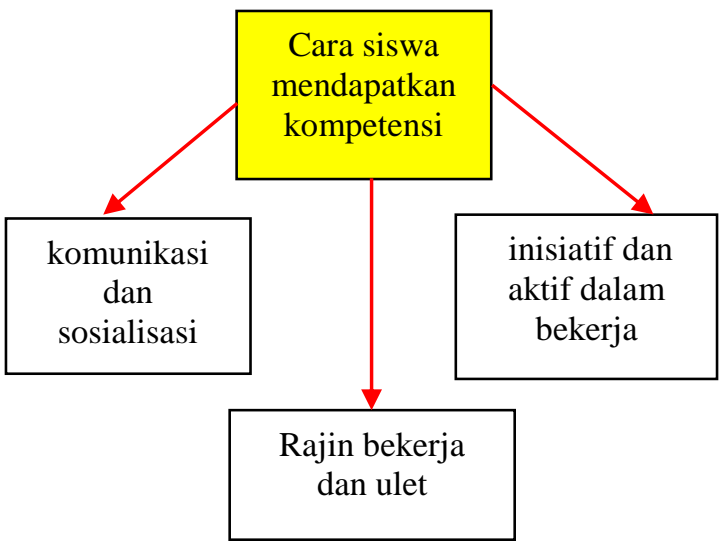

Gambar 3. Cara siswa mendapatkan kompetensi

Ada beberapa cara yang dilakukan siswa untuk mendapatkan kepercayaan mekanik untuk mengerjakan sebagian atau keseluruhan pekerjaan dengan bimbingan dan pengawasan mekanik (lihat gambar 3). Temuan penelitian berdasarkan pengalaman siswa melaksanakan prakerind, ada tiga cara yang dilakukan oleh siswa antara lain:

1) Berkomunikasi dan bersosialisasi dengan seluruh mekanik yang ada di bengkel. Pada bengkel Nasmoco Bantul memang menetapkan satu mekanik untuk diikuti karena mereka sudah memiliki pengalaman dalam melakukan training terhadap pekerja pemula. Namun siswa prakerind tidak ditetapkan pada suatu pekerjaan tertentu sampai tuntas dan kompeten seperti yang diberlakukan dalam training karyawan mereka. Pada bengkel menengah siswa tidak ditetapkan untuk mengikuti satu mekanik, tetapi siswa dimintai bantuan atau dengan inisiatif sendiri mendekati mekanik yang sedang bekerja. Disinilah kemampuan komunikasi dan sosialisasi siswa sangat dibutuhkan untuk mendapatkan kepercayaan dari mekanik melakukan pekerjaan secara bertahap dari tingkat resiko yang paling rendah sampai pada yang paling tinggi.
Berkomunikasi dan bersosialisasi dengan seluruh mekanik sangat penting dilakukan oleh siswa agar siswa dapat akses ke pekerjaan setiap saat. Misalkan suatu saat mekanik yang diikuti sedang tidak ada pekerjaan, siswa dapat mengikuti dan membantu mekanik lain yang sedang bekerja. Dalam Cunningham, Dawes dan Bennet (2004: 127-128), ada lima langkah dalam pelaksanaan pembelajaran yang dapat dilakukan peserta pembelajaran di tempat kerja, salah satunya adalah menjalin hubungan dengan rekan kerja dan yang lainnya untuk menggali ide-ide dan sumber-sumber potensi keahlian yang menantang untuk diri sendiri.

2) Rajin dan ulet bekerja. Kemauan yang kuat dari siswa untuk mendapatkan kompetensi di tempat kerja akan membuat siswa rajin dan ulet dalam bekerja. Kerajinan dan keuletan siswa dalam bekerja akan mendekatkan siswa pada pekerjaan dengan tingkat resiko yang paling tinggi. Tingkat kepercayaan mekanik kepada siswa untuk mengerjakan pekerjaan secara bertahap dari tingkat resiko yang paling rendah ke yang paling tinggi dengan indikator: siswa telah melakukan suatu pekerjaan secara berulang dengan hasil yang baik menurut mekanik.

3) Memiliki inisiatif dan aktif dalam bekerja. Mekanik sebagai pembimbing siswa dalam prakerind tidak disyaratkan untuk memberikan pelatihan dengan tata urutan tertentu, siswa hanya membantu pekerjaan mekanik sehari-hari. Keaktifan siswa dalam pekerjaan (misalnya menanyakan sesuatu yang belum dimengerti kepada mekanik) dan inisiatif siswa untuk menambah pengetahuan setelah melakukan pekerjaan baik melalui buku panduan maupun bertanya kepada orang yang lebih ahli (mekanik) agar pada pekerjaan yang sama berikutnya siswa dapat mengerjakan dengan baik dan benar merupakan salah satu cara bagi siswa untuk mendapatkan kepercayaan mekanik untuk mengerjakan pekerjaan dengan tingkat resiko yang lebih tinggi. Sehingga siswa dapat lebih efektif menjalankan perannya sebagai helper mekanik dan mendapatkan kompetensi secara maksimal dalam pelaksanaan prakerind. 
Ketiga cara yang dilakukan siswa untuk mendapatkan akses ke pekerjaan di atas relevan dengan Gewertz (2007) dalam Morley (2010: 21) menyatakan bisnis dan industri memberikan pesan yang sangat jelas bahwa siswa membutuhkan keterampilan untuk "bekerja dengan nyaman dengan orang-orang dari budaya lain, memecahkan masalah secara kreatif, menulis dan berkomunikasi dengan baik, berpikir dengan cara yang multidisiplin, dan mengevaluasi informasi kritis serta mereka harus tepat waktu, dapat diandalkan, dan rajin".

\section{Pengetahuan, keterampilan dan sikap yang diperoleh siswa}

Secara umum siswa memiliki pengetahuan tentang dunia kerja bengkel otomotif dan pengalaman kerja pada pekerjaan yang sesungguhnya. Kegiatan praktek kerja merupakan faktor kunci dalam konstruksi pengetahuan, dan partisipasi dalam aktivitas kerja sehari-hari merupakan "kekuatan" peserta didik untuk mengakses tingkat pengetahuan dan keterampilan. Pengulangan yang terjadi terhadap suatu kegiatan merupakan pengalaman yang akan menambah pengetahuan siswa, dan keterlibatan aktif dalam pemecahan masalah secara rutin dapat memberikan penguatan dalam belajar. Pengetahuan yang diperoleh dari dunia kerja merupakan bekal siswa agar tidak canggung lagi saat memasuki dunia kerja setelah menyelesaikan studinya di SMK.

Keahlian/skill adalah apakah seorang ahli tahu dan dia juga dapat melakukan. Orang yang memiliki kompetensi pada tingkat tertinggi disebut ahli. Kategori kompetensi manusia dalam taxonomi mulai dari orang yang belum berpengalaman sampai kepada master (Jacob \& Washington, 2003 dalam Jacobs (2002). Dalam temuan penelitian ini kategori kompetensi siswa yang diperoleh dalam prakerind untuk kategori bengkel besar dan kecil dalam kategori specialist. Artinya orang yang dapat di andalkan untuk melakukan pekerjaan yang spesifik tanpa pengawasan. Tetapi terbatas pada pekerjaan rutin. Kadang-kadang diperlukan pelatih pada tingkat ini untuk membantu mereka memiliki perilaku yang sesuai. Sedangkan untuk kategori bengkel menengah masih dalam kategori orang yang belum berpengalaman. Artinya siswa adalah orang yang baru pada suatu situasi kerja. Sebagai hasilnya, individu kurang pengetahuan dan keterampilan untuk memenuhi persyaratan yang dibutuhkan untuk melakukan pekerjaan tertentu.

Tingkat kompetensi yang diperoleh siswa disebabkan oleh pola pengaturan belajar oleh dunia usaha/industri dan pembimbingan siswa oleh mentoring/mekanik yang tidak terstruktur dalam pelaksanaan prakerind. Menurut Vaughan, O'Neil and Cameron (2011: 23) orang yang dipilih sebagai mentoring ini perlu memiliki berbagai keterampilan dan atribut pribadi. Untuk menjalankan perannya sebagai mentoring peserta didik, seorang praktisi ahli harus memiliki konten pengetahuan dalam pekerjaan sehingga mereka dapat membimbing peserta didik dalam memperoleh pengetahuan dan keterampilan yang dibutuhkan untuk keberhasilan pembelajaran. Membantu orang belajar memerlukan pengalaman dan keterampilan khusus dari seorang mentoring. Selain itu mungkin dalam periode yang terbatas, kinerja yang dicapai lebih rendah dari yang diharapkan (Cunningham, Dawes dan Bennet, 2004: 127-128).

Attitude. Secara tidak langsung, pelaksanaan prakerind akan membentuk sikap siswa sesuai dengan budaya kerja di DUDI. Dengan jam kerja jam kerja rata-rata di atas 40 jam per minggu dan tidak jarang bekerja melebihi jam kerja normal yang ditetapkan dunia kerja siswa akan terbiasa bekerja keras. Selain itu siswa akan memiliki kepedulian yang berkaitan dengan mutu, di mana tidak boleh gagal dalam bekerja karena kegagalan adalah kerugian yang harus ditanggung oleh pekerja dan perusahaan. Mekanik selaku pengawas dan pembimbing siswa dalam bekerja selalu melakukan pengecekan kembali pekerjaan yang telah dilakukan oleh siswa.

\section{Pembahasan Hasil Penelitian}

1. dikonseptualisasi dan dievaluasi. Tanpa adanya identifikasi, konseptualisasi dan pengakuan dari kurikulum berbasis tempat kerja, maka tempat kerja akan tetap disalah pahami sebagai tempat belajar (Billet: 2006).

\section{Membatasi jumlah siswa dalam pekerjaan}

Dari tiga kategori bengkel yang diteliti yaitu bengkel besar, menengah dan kecil, setiap bengkel membatasi jumlah siswa dengan cara yang berbeda. Bengkel Nasmoco Bantul dengan kategori besar membatasi jum- 
lah siswa dengan kuota tertentu berdasarkan banyaknya pekerjaan setiap bulannya. Misalnya kuota yang ditetapkan setiap bulannya adalah 6 siswa, jika bulan berikutnya ada siswa yang keluar atau telah selesai dalam pelaksanaan prakerind maka akan diisi oleh siswa berikutnya. Oleh karena itu sekolah harus sudah memasukkan permohonan prakerind 6 bulan sebelum pelaksanaan. Berbeda dengan bengkel Rally Autocare dengan kategori menengah yang langsung membatasi jumlah siswa untuk setiap periode prakerind dan terbatas pada sekolah tertentu yaitu sekolah dengan status negeri. Alasannya adalah sekolah negeri lebih disiplin dan sopan sehingga memudahkan mereka dalam pembimbingan dan pengawasan. Pada bengkel menengah lainnya yaitu bengkel Maestro pembatasan jumlah siswa didasarkan pada banyaknya pekerjaan. Jika jumlah siswa melebihi pekerjaan yang ada maka akan diadakan pembagian waktu kerja yaitu pagi dan siang. Pada bengkel Agus dengan kategori kecil, di mana pemilik sekaligus mekanik yang membimbing siswa membuat pengaturan dengan pola estafet. Misalnya ada tiga siswa dari sekolah yang sama melaksanakan prakerind selama 3 bulan tetapi baru berjalan satu setengah bulan pihak bengkel akan menambah 3 siswa lagi dengan sekolah yang berbeda. Pengaturan seperti ini dimaksudkan untuk memudahkan pemilik bengkel membimbing dan mengawasi siswa sebagai pekerja pemula dan mencegah terjadinya kekosongan bengkel dari siswa prakerind. Pembatasan jumlah siswa oleh dunia kerja dimaksudkan untuk memudahkan mekanik mengawasi dan membimbing siswa dalam belajar melalui pekerjaan. Pembimbingan dan pengawasan siswa oleh mekanik merupakan syarat mutlak dari perusahaan untuk menghindari terjadinya kesalahan dan kegagalan dalam pekerjaan yang mungkin dilakukan oleh siswa sebagai pekerja pemula. Karena kesalahan dan kegagalan dalam pekerjaan merupakan kerugian yang harus ditanggung oleh pekerja/pengusaha.

\section{Menjadikan siswa sebagai helper mekanik}

Selain membatasi jumlah siswa, dunia kerja juga menjadikan siswa sebagai helper mekanik yang akan membantu pekerjaan yang dilakukan oleh mekanik. Pada bengkel dengan skala besar yang memiliki pengalaman dalam melakukan training terhadap pekerja pemula memberikan pengaturan dengan menetapkan satu mekanik untuk diikuti/dibantu walaupun tidak tertutup kemungkinan siswa akan membantu mekanik lain. Siswa dapat mengikuti mekanik lain jika mekanik yang ditetapkan sedang tidak ada pekerjaan, namun tetap di bawah koordinasi mekanik dan foreman sebagai atasan mekanik. Dalam mengikuti mekanik, siswa tidak ditetapkan pada satu pekerjaan seperti program sekolah dengan sistem edukasi oleh perusahaan mereka, tetapi siswa membantu pekerjaan yang dilakukan oleh mekanik. Pada bengkel dengan skala menengah tidak menetapkan satu mekanik untuk diikuti oleh siswa, siswa bebas mengikuti mekanik mana saja atau mereka diminta membantu oleh salah satu mekanik untuk membantu pekerjaannya. Bengkel dengan skala kecil langsung menjadikan siswa sebagai helpernya karena pemilik bengkel sekaligus sebagai kepala mekanik. Siswa akan bekerja membantu setiap pekerjaan sesuai dengan instruksi dan arahan dari mekanik. Proses belajar siswa pada komunitas praktek dalam pelaksanaan prakerind dengan mengikuti pekerja yang lebih berpengalaman relevan dengan teori situated learning. Situated learning diproyeksikan oleh Lave dan Wenger (1990) sebagai model pembelajaran dalam komunitas praktek. Dengan mengikuti mekanik memungkinkan individu (siswa/pelajar) untuk belajar dengan sosialisasi, visualisasi, dan imitasi. Dalam teori situated learning belajar merupakan proses sosial (Goodnow: 1990 dalam Billet: 1994) dan terjadinya proses bimbingan sosial langsung dan tidak langsung antara pelajar dengan orang yang lebih berpengalaman dipandang sebagai bagian penting dan tak terelakkan dari proses pembelajaran (Cazden: 1993, Goodnow: 1990, Rogoff: 1990 \& dalam pers; Scribner: 1985 \& 1990; Vygotsky: 1978 dalam Billet: 1994).

Pengaturan belajar di tempat kerja dimaksudkan untuk mengatur keterlibatan siswa dalam belajar melalui pekerjaan. Dalam temuan penelitian, keterlibatan siswa dalam belajar melalui pekerjaan diatur oleh dunia kerja melalui pembatasan jumlah siswa dan menjadikan siswa sebagai helper mekanik. Pengaturan ini tidak tertulis dan dapat dikatakan sebagai kurikulum tersembunyi tetapi dilakukan oleh dunia kerja berdasarkan dari pengalaman pelaksanaan prakerind sebelumnya. Secara tidak langsung dunia kerja telah 
mengevaluasi pelaksanaan prakerind agar dapat berjalan efektif dan saling menguntungkan.

Secara umum, pengaturan yang dilakukan oleh perusahaan mencerminkan keinginan seseorang atau pihak tertentu yang ada di DUDI terhadap pengalaman yang akan didapat oleh siswa. Hal ini tercermin dari pengaturan yang dilakukan oleh dunia kerja melalui pengelola dan rekan kerja. Pengusaha/pengelola dalam hal ini pemilik/manager/instruktur bengkel dan mekanik sebagai rekan kerja. Menurut Billet (2006) keputusan tentang akses dan dukungan untuk siswa terhadap pengalaman yang akan didapat dalam belajar di tempat kerja kemungkinan besar akan datang dari tiga sumber: (1) pengusaha / pengelola, (2) rekan kerja, dan (3) pelayanan dan faktor-faktor produksi. Namun mereka hanya mengatur akses ke kegiatan dan interaksi siswa dalam belajar dan memberikan dukungan serta mengatur untuk kemajuan peserta didik.

\section{Kepedulian pada penyiapan tenaga kerja tingkat menengah oleh SMK}

Dalam temuan penelitian ini dunia kerja menyadari keterbatasan sekolah dalam menyiapkan lulusan yang terampil dan memiliki pengalaman nyata bekerja di dunia kerja yang sarat nilai. Oleh karena itu dunia kerja memberikan kesempatan kepada siswa SMK untuk belajar di tempat mereka dengan harapan SMK dapat memiliki lulusan yang berkualitas. Disamping itu kebutuhan akan tenaga mekanik sebagai generasi penerus menjadi alasan lain dari dunia kerja memberikan dukungan terhadap pelaksanaan prakerind.

\section{Kebutuhan tenaga kerja jangka pendek}

Temuan lain dari penelitian ini adalah dunia kerja dapat memanfaatkan tenaga kerja siswa prakerind untuk memenuhi kebutuhan tenaga kerja mereka. Disinilah terjadinya hubungan yang saling menguntungkan antara sekolah dan dunia kerja. Dunia kerja mendapatkan tenaga kerja secara cuma-cuma dan siswa mendapatkan pengalaman kerja sarat nilai sebagai bekal mereka setelah lulus.

Pemberlakuan pengaturan belajar/kurikulum di tempat kerja tergantung pada faktor tempat kerja yang pada akhirnya dialami oleh pekerja sebagai peserta didik. Jadi kemungkinan untuk merealisasikan pengaturan bel- ajar/kurikulum tersebut didasarkan pada dukungan yang diberikan DUDI terhadap kepentingan peserta didik di tempat kerja. Sama seperti di lembaga pendidikan, dukungan dari tempat kerja menekankan pada peranan pengaturan keterlibatan individu dalam belajar melalui pekerjaan yang terdiri dari norma-norma dan praktek-praktek sosial yang berlaku di tempat kerja (Billet: 2006).

\section{SIMPULAN DAN SARAN}

\section{Simpulan}

Pengaturan belajar siswa di tempat kerja dengan membatasi jumlah siswa dalam pekerjaan dan menjadikan siswa sebagai helper mekanik secara tidak langsung hanya untuk memudahkan pihak DUDI dalam melakukan pembimbingan dan pengawasan terhadap siswa prakerind.

Motivasi DUDI menerima siswa prakerind merupakan salah satu indikator terlaksananya prakerind dengan efektif. Motivasi DUDI tersebut antara lain: (1) kepedulian pada penyiapan tenaga kerja tingkat menengah oleh SMK (2) kebutuhan akan tenaga kerja jangka pendek.

Belajar melalui pekerjaan dengan mengikuti mekanik. Peran mekanik sebagai instruktur/pembimbing dalam proses belajar siswa di DUDI antara lain: (1) memberikan kesempatan kepada siswa untuk melakukan pekerjaan secara langsung dengan bimbingan dan pengawasan; (2) memberikan penilaian terhadap kinerja siswa (apakah siswa akan diberikan kepercayaan untuk bekerja mandiri atau tidak)

Kompetensi yang diperoleh siswa dalam prakerind. Pada umumnya pekerjaan yang dilakukan siswa di tempat kerja sesuai dengan kompetensi di sekolah yang tertuang dalam kurikulum kompetensi keahlian teknik kendaraan ringan. Artinya terdapat korelasi antara kompetensi yang diajarkan di sekolah dengan jenis pekerjaan di tempat kerja.

Cara siswa mendapatkan kompetensi di tempat kerja: (1) berkomunikasi dan bersosialisasi dengan seluruh mekanik yang ada di bengkel; (2) rajin dan ulet bekerja; (3) memiliki inisiatif dan aktif dalam bekerja.

Pengetahuan, keterampilan dan sikap yang diperoleh siswa di tempat kerja: (1) Secara umum siswa memiliki pengetahuan ten- 
tang dunia kerja bengkel otomotif dan pengalaman kerja pada pekerjaan yang sesungguhnya; (2) kategori kompetensi siswa yang diperoleh dalam prakerind untuk kategori bengkel besar dan kecil adalah kategori specialist, sedangkan untuk kategori bengkel menengah masih dalam kategori orang yang belum berpengalaman; (3) membentuk sikap siswa sesuai dengan budaya kerja di DUDI yaitu kerja keras dan peduli mutu.

\section{Saran}

Bagi peneliti selanjutnya untuk lebih mendalami tentang hubungan siswa dengan mekanik sebagai pembimbing dalam prakerind dan melakukan pengembangan dengan memberikan panduan belajar kepada siswa serta mengidentifikasi terlebih dahulu kompetensi yang sesuai dengan lingkungan tempat kerja.

Sekolah atau guru kompetensi keahlian teknik kendaraan ringan hendaknya mengidentifikasi kompetensi di tempat kerja yang sesuai dengan kompetensi yang ada disekolah. Setelah diidentifikasi, siswa diberikan materi yang sesuai untuk dipelajari dan sebagai panduan selama pelaksanaan prakerind. Sehingga siswa yang akan prakerind selanjutnya sudah mendapatkan gambaran dan memiliki panduan tentang kompetensi yang akan dipelajari di DUDI tersebut.

Sekolah dalam hal ini guru dapat mengevaluasi tingkat kompetensi yang diperoleh siswa di tempat kerja sebagai bentuk ketuntasan belajar.

Semua mekanik di DUDI sudah seharusnya memiliki pengalaman training, agar mereka juga mengetahui bagaimana melatih siswa prakerind.

\section{DAFTAR PUSTAKA}

Billett, S. (1994). Situated learning - a workplace experience. School of Adult \& Vocational Education. Faculty of Education Griffith University Australian Journal of Adult and Community Education, 34 (2) 112-130.

Billett, S. (2006). Constituting the workplace curriculum. dalam Patricia Murphy \&
Robert McCormick (2008). Knowledge and practice: Representation and identities. London: SAGE Publications Ltd.

Cunningham, I., Dawes, G., \& Bennett, B. (2004). The handbook of work based learning. Burlington: Gower Publishing Company

Djojonegoro, W. (1998). Pengembangan sumber daya manusia melalui sekolah menengah kejuruan $(S M K)$. Jakarta: Jaya Agung Offset

Daya serap lulusan SMK masih rendah. (2008, 31 Maret). http://www.kapanlagi.com.p. 2.

Finch, C. R., \& Crunkkilton. (1999). Curriculum development in vocational and technical education. Massachusetts: Allyn \& Bacon. Inc.

Inilah penyebab utama lulusan SMK sulit terserap di dunia industri. (2012, 23 Maret). http://www.republika.co.id, p. 2.

Jacobs, R. L. (2003). Structured on-the-job training: Unleashing employee expertise in the workplace. San Fransisco: Berrett-Koehler Publishers, Inc.

Lave, J., \& Wenger, E. (1990). Situated learning: Legitimate periperal participation. Cambridge, UK: Cambridge University Press

Morley, R. (2010). Workplace learning guide 2010 learning for life in the 21st century. (e-book) http://www.iowaworkforce.org/ files/wlg02.pdf. p. 21-40

Vaughan, K., O’Neil, P., \& Cameron, M. (2011). Successful workplace learning: How learning happens at work. New Zealand Council for Educational Research: Industry Training Federation. Diambil pada tanggal 08 Desember 2012 dari http://www.itf.org.nz/assets/ Publications/ Successful-WorkplaceLearning-2011.pdf.

2014, 70 persen lulusan SMK terserap pasar kerja. (2010, 26 Januari). http://www. kompas.com, p. 2. 